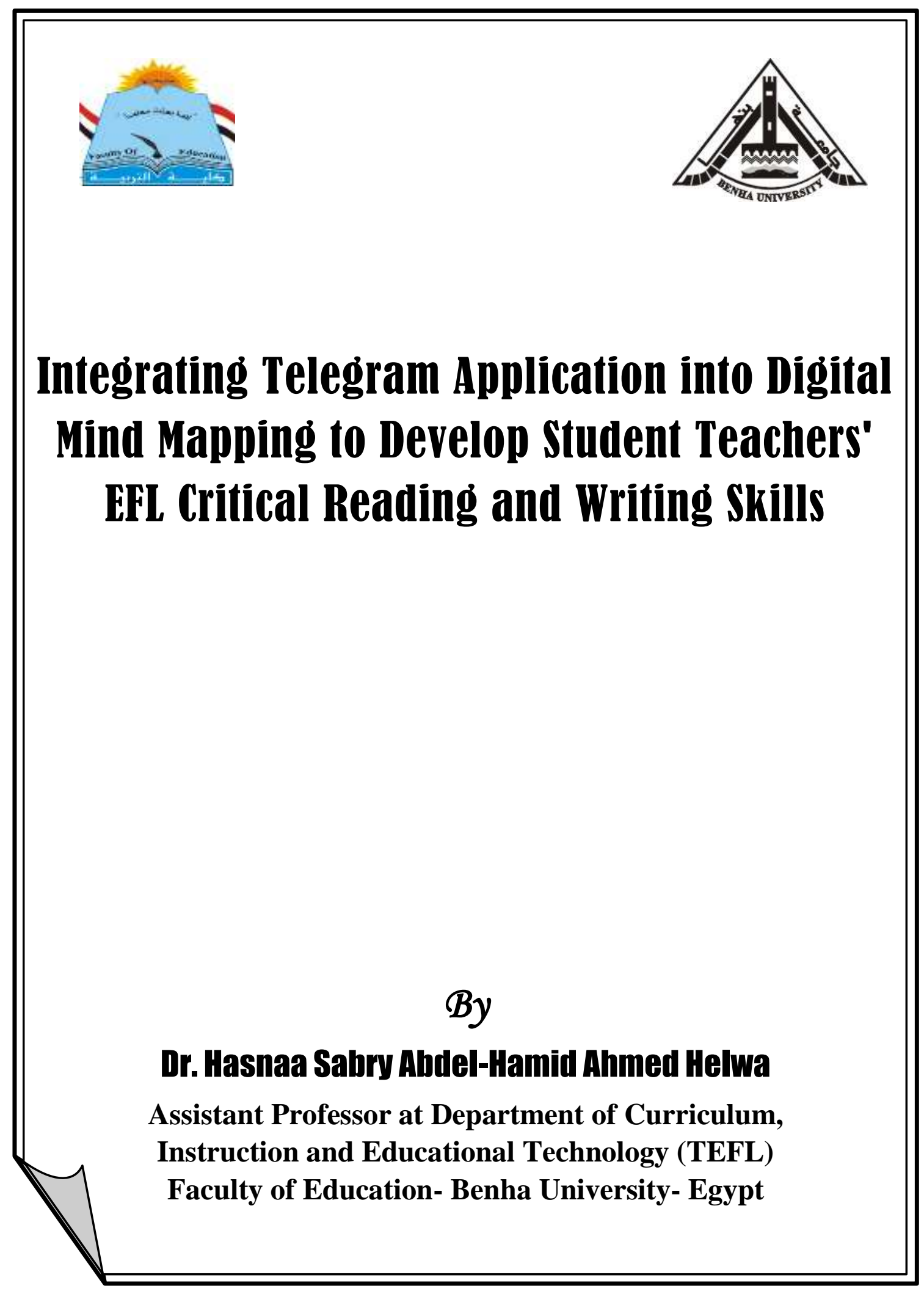




\section{Integrating Telegram Application into Digital Mind Mapping to Develop Student Teachers' EFL Critical Reading and Writing Skills}

\section{Ahstract}

The study aimed to investigate the effectiveness of integrating telegram application into digital mind mapping in developing student teachers' EFL critical reading and writing skills. The design of the study was a mixed research methodology. It combined both quantitative and qualitative methods of collecting data. The participants of the study were thirty -five $(\mathrm{N}=35)$ students enrolled in third -year English section at the Faculty of Education, Benha University, Egypt. They were tested before and after the treatment. They were taught through using digital mind mapping and telegram application based program. The instruments of the study included an EFL critical reading skills test, an EFL critical writing skills test and a semi-structured interview. The results of the study revealed a statistically significant difference between the mean scores of the study participants in the pre and post administrations of the EFL critical reading and writing skills tests in favor of the post administrations. These results were ascribed to digital mind mapping and telegram application based program.

Keywords: Digital Mind Mapping - Telegram Application - EFL Critical Reading Skills - EFL Critical writing Skills.

\section{1}


دمج تطبيقى التلبجرام (Telegram) فى الخرائط الذهنية الرقمية لتنمية مهارات

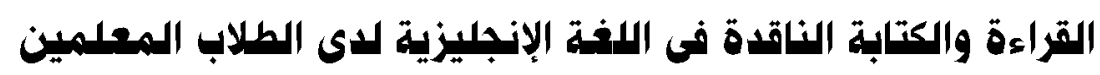

$$
\text { ! }
$$

أ.م.A/ هسناء صبرى عبدالحميد أهمد هلوه

أستاذ مساعد بقسم المناهج وطرق التدريس وتكنولوجيا التعليه

(تخصص لغة إنجليزية) كلية التربية - جامعة بنها

\section{المستخلص بالاغة العربية}

تهدف الدراسـة إلى توضـيح فاعليـة دمـج تطبيق التليجـرام (Telegram) ف الخرائط

الذهنيـة الرقميـة فـى تتميـة مهارات القراءة والكتابـة الناقدة فـى اللغـة الإنجليزيـة لدى الطـلاب المعلمين بكلية التربية ـ ويعد هذا البحث من البحوث المختلطة / المدمجة التى دمجت أساليب البحث الكمية والكيفية معا. وتكونت عينة الدراسة من خمسة وثلاثون من الطلاب المعلمين تم اختيارهم عشوائيا مـن طـلاب الفرقة الثالثة شعبة اللغـة الإنجليزيـة بكليـة التربيـة جامعـة بنها,

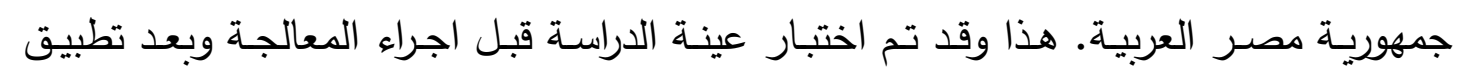
البرنامج القائم على دمج تطبيق التليجرام (Telegram) ف الخرائط الذهنية الرقمية. واشتملت ادوات الدراسة على اختبار فى مهارات القراءة الناقدة فى اللغـة الإنجليزيـة , اختبار فى مهارات

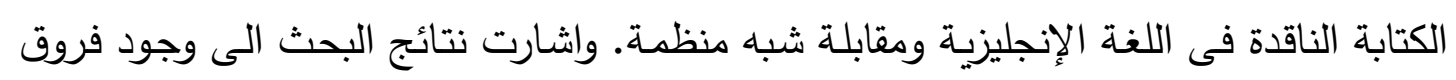

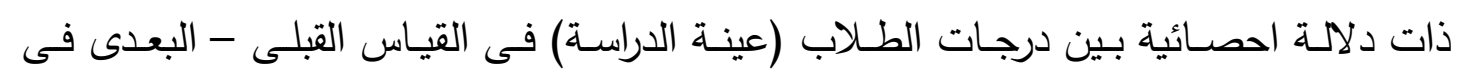
مهارات القراءة والكتابة الناقدة فى اللغة الانجليزيـة لصـالح القياس البعدى ـ وترجع هذه النتائج الى فاعلية البرنامج القائم على دمج تطبيق التليجرام (Telegram) ف الخرائط الذهنية الرقمية فى تتمية تلك المهارات لدى الطلاب المعلمين .

الكلمـات المفتاحيـة: الخرائط الذهنية الرقمية - تطبيق التليجرام (Telegram)- مهارات القراءة الناقدة فى اللغة الإنجليزية - مهارات الكتابة الناقدة فى اللغة الإنجليزية. 


\section{Introduction}

English language is a tool for communicating ideas and information all over the world. Communication is the main function of language and essential for language learning especially in the age of information and communication technologies (ICTs).Language learning is divided into language skills and language systems. The four language skills (listening, speaking, reading and writing) are classified into receptive and productive skills. The receptive skills are listening and reading where learners receive the information and do not have to produce it. On the other hand, speaking and writing are productive skills where learners need to produce spoken and written language to communicate.

Reading is one of the most significant skills students must possess. It is the basis of all English language skills. It helps EFL students to communicate, listen and express themselves freely. It also allows them to acquire specific language skills. It is a source of information and helps in clarifying inaccurate points, solution of problems, a target of language acquisition and academic success. It enables learners to be engaged in the learning process that occurs subconsciously without stress or special effort (Ceylan \& Baydik, 2018, Öztürk, 2018).

Chaichompoo (2017) reported that while individuals read, they make an attempt to translate, interpret and analyze what is explicitly and implicitly presented in the text to understand what the writers mean and the messages they attempt to put across. In reading, students should learn how to separate main ideas from supporting details. This skill helps them to focus mainly on the gist of the reading passage. Also Goctu (2016) clarified that students are engaged in reading not because they have to, but they satisfy their need in getting information. Through reading, learners see the relationship between words and sentences and understand how words work in sentences. This relationship will enable learners to use the language effectively. Alfallaj (2017) indicated that in 
a reading class, teachers help their students reach the right answer by matching words in the question with those in the text.

It can be said that reading is an essential skill in information and technology age because it has an effect on obtaining knowledge and improving experience.It includes different skills such as critical reading skill (CR). CR as a pattern of critical thinking is the ability of readers to discuss what they were reading and analyzing what the author was writing. It requires the reader to be competent in differentiation and comparison skills, analytical skills such as drawing conclusion and evaluation skills such as giving opinion and judgments. It is a process of interaction between the reader and the text, where the readers effectively analyze and criticize the text using their experiences, knowledge and what is contained in the text, such as hints, signals, symbols and clues. Thus, it can be said that $\mathrm{CR}$ is one of the skills required for the 21 st century. It refers to questioning and evaluating what the readers are reading because they are unable to assess something they do not understand. The essential element in CR is understanding what they are reading and finding out the strengths and weaknesses in the text (Küçükoğlu, 2013).

Haromi (2014), Karabay (2015) \& Karaca \& Oguz (2017) clarified that $\mathrm{CR}$ is a meta-cognitive process where the readers interact with texts, ask questions, predict and make connections through previous knowledge and experiences. It is active reading that enables the learners to do an action. It requires more than the ability to understand the meaning of the passage in a clear way. It also includes application, analysis, evaluation and imagination. It is an analytical process requiring an active reading, asking questions about the text, developing hypotheses and judgments. CR plays an important role in accepting the arguments of the author by questioning, criticizing, investigating from reliable sources, using the mind and self-criticism to distinguish the facts, making judgments by making inferences, understanding and interpreting themselves and the world, instead of directly accepting outside information or the author`s point of view. 
It can be said that $\mathrm{CR}$ originated from critical thinking. It is the application of critical thinking to the reading process. In CR, readers are trying to find information and ideas inside the text. It is done by analyzing, synthesizing, drawing inference, interpreting and evaluating what they are reading. CR is a reading activity which applies the concept of critical thinking. The readers try to read using analytical methods to understand the text message, the language used in the text and the text arrangement. Furthermore, critical readers will respond to the writers' role and intent based on different perspectives related to their previous knowledge of the text (Lestari, 2015).

Abd Kadir, Subki, Jamal \& Ismail (2014) indicate that the main concern in CR is helping students interpret the text critically such as reading between the lines or reading for deeper meaning .Students would have strong reading comprehension skills when their teachers helped them improve CR skills. Students with good reading comprehension skills could perform well in any subject because they have developed CR skills not only understand but analyze any text given to them. Tomasek (2009) clarifies that students are able to read critically in a variety of ways. Examples include posing crucial questions and problems from the text, gathering and analyzing relevant information and then giving interpretations of that information. They also includes testing interpretations against previous knowledge or experience and current experience, investigating their assumptions and the implications of those assumptions and using what they have read to communicate effectively with others or creating possible solutions to complex problems.

CR makes readers recognize, detect, respond to and connect the ideological purposes of diction used by the author of a given context. It is a process where the readers, text and writers interact with each other. There are different definitions of CR. For example, Maltepe (2016) defines it as the individuals' thinking about what they read, assessing what they have read and using their own judgment about what they have 
read. Thus, in order to teach CR skills to students, a teacher is expected to have knowledge about text selection, use of appropriate methods, preparation of functional learning and teaching processes. According to Ulu, Avşar-Tuncay \& Baş (2017) and Sriwantaneeyakul (2018) CR is a kind of reading based on acquiring high-level thinking skills and requires reading between lines. Nasrollahi, Krishnasam \& Noor (2015) define CR as an interactive process uses a variety levels of thought and critical readers are asking questions about the text they are reading.

Damaianti, Damaianti \& Mulyati (2017) illustrate that critical readers should be active readers, asking questions, looking for facts and suspending judgment until they assume right .Abd Kadir, Subki, Jamal\& Ismail (2014) indicate that CR skills help students analyze, synthesize and evaluate what is read. Yu (2015) states that to read critically, readers should actively recognize and analyze information they read on the text. They also need to read between the lines. Abdel -Halim (2011) states that CR helps students become better readers and thinkers because they will look at reading as a process rather than a product. Thus, it can be found that texts on CR ask students to recognize an author's purpose, understand tone and persuasive elements and recognize bias.

IÇMEZ (2009) and Zabihi \& Pordel (2011) confirm that critical readers should have the ability to assess and conclude the value of a text by looking into the arguments and assessing the evidence provided. Students need to be able to read critically because they have good CR skills that help them go beyond the information given by asking questions, making hypotheses, seeking evidence, and validating conclusions. Therefore, students who are exposed to CR skills are able to identify and synthesize the knowledge. It can be concluded that CR aims at providing an environment for genuine two-way communication in the classroom, where the students can teach the teacher as much as the opposite .In the same context, Anuar \& Sidhu (2017) clarified that CR is a challenging skill. It is not only limited to understanding the text, but also determine accuracy of facts and its interpretations through the 
assessment process of the opinions or knowledge. It is the ability to make judgments and inferences, distinguish between facts and opinion and recognize the author's purpose or points of view. Therefore, Abd Kadir, Subki, Jamal \& Ismail (2014) revealed that students would be able to analyze, synthesize and evaluate information in the text easily if they acquire CR skills from an early stage.

It can be noted that CR skills are the skills that may help students to be able to analyze, synthesize and evaluate what is read. When teachers expose students to CR skills, they will also make them see the cause and effect or comparing relationships in the text or adopting critical stance toward the text. In other words, when teachers teach CR skills to students they will develop them to be critical thinkers as well because when they do CR it will lead to critical thinking (CR will come first before critical thinking). In their study, Abd Kadir, Subki, Jamal \& Ismail (2014) revealed that students needed to understand the reading text to analyze, synthesize and evaluate it.

Because of the importance of EFL critical reading skills, researchers conducted studies to develop CR skills at the university level such as:

Abdel Halim (2011) confirmed the effectiveness of a task-based translation program in improving EFL majors' critical reading skills and political awareness. Albeckay (2014) clarified the impact of using innovative CR Programme for enhancing CR skills among undergraduate students in Libya. Karadağ (2014) explored primary school teachers' views towards $\mathrm{CR}$ skills and their perceptions of competence. The participants were fourth year students at the Education Faculty of Adiyaman University. The results revealed that critical reading skills are required for primary school teachers. Moreover, Khonamri \& Sana'ati (2014) investigated the effect of dynamic assessment and computer assisted language learning (DACALL) on developing Iranian EFL students' CR. Karabay (2015) examined the effects of understanding CR 
theories on using external reading strategies such as note-taking and underlining when confronting an ironical literary text.

In addition, Balıkçı \& Daloğlu (2016) conducted a case study to observe and investigate the critical reading discourse (CRD) of freshman pre-service teachers of English at the department of foreign language teaching at a state university in Turkey. The results indicated that the critical reading discourse of the freshman pre-service teachers of English involves interpretive, evaluative and responsive discourse. Sultan, Rofiuddin, Nurhadi \&Priyatni (2017) clarified the effect of the critical literacy approach on improving pre-service language teachers' CR skills. The CR skills measured consisted of six levels: interpretation, analysis, inference, evaluation, explanation, and self-regulation. The results revealed that the critical literacy approach had a significant effect on the pre-service language teachers' CR skills. Ulu, Avşar-Tuncay \& Baş (2017) investigated the relationship between the multimodal literacy of preservice teachers and their perception of self-efficacy in CR. The results revealed a positive and significant effect on CR self-efficacy perception.

In addition to $\mathrm{CR}$, Critical writing $(\mathrm{CW})$ is not necessarily writing about the topic in a negative way, it is simply making sure that writers have considered all sides of the argument. In reading students are likely discover different authors with different views. It is the job of a critical writer to consider all of these views in their essay to show their awareness of all the issues associated with their topic. Moreover, ATAÇ (2015) mentioned four features of Wythe first feature clarifies that CW requires a clear and confident refusal to accept the conclusions of other writers without evaluating the arguments and evidence that they provide. The second feature is that $\mathrm{CW}$ should include a balanced presentation of reasons why the conclusions of other writers may be accepted or may need to be treated with caution. The third one focused on a clear presentation of evidence and argument that leads to a conclusion. The last feature includes recognition of the limitations in evidence, argument, and conclusion. 
LIU(2006) clarified that CW was determined by the writer's ability to respond to a text with logical and critical analysis and attention to its thematic argument. Inexperienced writers require training and modeling to arrive at the stage of expressing their thoughts logically. Writing as a process takes careful planning, repeated and orchestrated strategic activities. Thus, implementing the writing-to-learn in the curriculum does not guarantee critical thinking and the idealized result of writing to learn. To maximize the learning outcome by reinforcing critical thinking, student writers must be made aware of effective strategies as the first step in the learning process .

$\mathrm{CW}$ is about developing a person's own academic voice within his or her subject area. It is the result of an ongoing process of reflecting, researching, note-taking, reading and writing. It needs much higher level of skills. Critical writers participate in the academic debate. They need to weigh up the evidence and arguments of others and contribute their own opinions. They need to consider the quality of the evidence and argument they have read. They should identify key positive and negative aspects they can comment upon. They assess their relevance and usefulness to the debate that they are engaging in for assignment and identify how best they can be woven into the argument that they are developing (ATAÇ, 2015).

Critical thinking and CW skills are one of the core requirements and necessary tools required in Higher Education. In his study, Ahmed (2018) clarified that although students were aware of what critical thinking and $\mathrm{CW}$ were, they required explicit instruction on how to apply and demonstrate these concepts in their assignments. Moreover, Kahu \& Gerrard (2018) stated that personal experience as a strategy was developing assessment tasks. This task encourages students to use their existing experiences and beliefs to generate and ground their critical commentary on reading material. This approach allows students to practice and develop key skills and dispositions in CR and CW. In their 
study ,El Ganzoury, Ghanem \& Hafez (2019) stated that CW focused on presenting evidences, ideas and points of view in a clear manner. It is the process that involves using a wide range of writing abilities. Thus, it can be concluded that it is the job of a critical writer to consider all of these views in their essay to show their awareness of all the issues associated with their topic.

Because of the importance of EFL critical writing skills, researchers conducted studies to develop $\mathrm{CW}$ skills at the university level such as:

In her study, Abdel Latif (2012) investigated that using a blended learning literature based program is effective in enhancing CR and CW skills and developing literature appreciation of first -year English majors at the Faculty of Education. El-Attar (2013) confirmed the effect of a suggested program based on discourse analysis and metacognitive awareness on developing EFL trainees' critical writing skills and foreign language cultural awareness. Ahangari \& Sepehran (2014) investigated the effect of intertextuality on learners' CW skill among advanced EFL students at the Iran Language Institute . Moreover, ATAÇ (2015) investigated the critical thinking skills and $\mathrm{CW}$ of the first year students registered at the ELT Department in Nevsehir H. B.V. University. The results of the study indicated that the critical thinking and critical writing are interrelated and the students usually have a positive opinion about the relationship between them.

Linh (2016) conducted a study to develop an instructional design model for assisting students in learning collaboratively using Facebook groups to enhance their English writing skills at the beginning stage of their university education. Madkour, Kotb \& Ramadan (2016) confirmed that using E-learning strategy based on the reflective approach is effective in enhancing at the Faculty of Education English majors' CW skills. Zahran (2018) confirmed the effect of using project based learning on developing EFL CR and writing skills among students at the university level. Ibrahim (2018) revealed the effect of a suggested 
eclectic approach on developing EFL critical and writing skills for English section students at the Faculty of Education- Helwan University.

The current era is characterized by rapid changes surrounded by many challenges. In order to cope with these rapid developments, it is important to pay attention to the development of creative minds capable of solving existing problems. Searching for new approaches provides teachers with deeper reflection of students' knowledge and improves the educational process through various approaches (Simonova, 2013, Malkawi \& Smadi, 2018).

One of these approaches is mind mapping. It is a method used to generate, visualize, structure and classify ideas to help human memorize. It can show relationships between all key words at all levels clearly and build the memory link from key words to pictures and colors. It utilizes both left and right hemisphere of brain and can be used as a memoryaiding tool. It develops students' ability to comprehend and understand the meaning of a text .It also activates prior knowledge, encourages learners to ask questions, scaffold reading, listening comprehension, speaking and written production and assess oral production. Mind mapping activities require students to actively engage in their learning by connecting their prior knowledge to new information. When creating a mind map, a student frequently interacts with a textbook, notes from class, an instructor, classmate or study group (Jones, et.al. 2012, Kedaj, Pavlíček \& Hanzlík, 2014, Masoud \& Ibrahim, 2017,Chang, Chiu, \& Huang, 2018, Othman, 2018).

Nowadays, information technologies are developed and wide spread. Thus, digital mind maps become more popular. Papushina, Maksimenkova \& Kolomiets (2017) reveal that the creation of digital mind maps process is strongly supported by different software, but little is known about this software application to educational needs. Aljaser (2017) clarified that there are two types of mind maps. The traditional mind maps drawn manually by using paper and pen or on the board. On 
the other hand, the electronic mind maps apply the same steps through using computer software that automatically generate flow branches of ideas derived from the central one. Moreover, ideas can be edited or moved while images and symbols can be added. E-Mind Maps are more effective and attractive than traditional ones, since they depend on using professionally fast and specialized computer software which includes photos, colors, and drawings that attract the reader.

Traditionally, mind maps were drawn with colored pens and paper. With presently available technology, it is possible to create mind map by using computer, which makes it easy to make, review, revise and save mind maps. Moreover, such computer technology is useful in creating more presentations (Tungprapa, 2015).Mind mapping software can have various forms from representations of objects to hierarchical and cyclical structures. It has been classified into five major categories according to their structures such as star web, chart matrix, tree map, chain and sketch. Thus, Bahadori \& Gorjian (2016) concluded that using mind mapping software increased students' curiosity and motivated them to follow the new way of teaching vocabulary in reading skill. In her study, Al-Jarf (2010) showed how mind-mapping software used to help EFL freshman students learn, retain, apply and relate words sharing the same root or base. Also, Alwattar \&Al-Balhan (2018) clarified the effectiveness of using E-mind mapping strategies in improving vocabulary skills.

Aljaser (2017) confirmed that electronic mind maps (e-Mind Maps) facilitated the memorization of previous information and provided the participants with feedbacks. They also allowed fast revision of the topics before the test. They linked the information to colors and material items that contributed to focusing the subject in mind. In other words, they linked written information to drawings and symbols. Accordingly, the learners learnt better when using both hemispheres. Simonova (2013) clarified that innovations in each subject are always connected to searching for, discovering, introducing, piloting and testing new means 
of evaluation that will enable teachers to understand the learner's understanding of terms and their individual structure of knowledge. The information and communication technologies can be used for this purpose as well, e.g. electronic applications for creating and analyzing the mind maps, which are available on web pages of iMind-Map, brainstorm and mind map online, Edraw Mindmap.

Chaichompoo (2017) indicates that using e-mapping approach requires students to read more critically and analytically to create better mapping and summaries. This approach required students to read the passages prior to classroom both in groups and individually. It also encourages and inspires them to learn cooperatively as well as to develop teamwork skills and constructive discussions. Thus, in her study Al-Jarf, (2011) shows how mind-mapping software can be integrated in EFL courses. Zaki, Gheith, Nassar \& Al Saify (2014) defined electronic mind mapping as a digital non-linear web activity that constructs a unique cognitive structure and enables students to practice critical reading. Thus, their study focused on investigating the effect of using Electronic mind mapping on developing EFL critical reading skills.

E-mapping can organize and sequence content nonlinearly on one web page by placing the main topic in image centered diagram with interrelated main and subtopic connections or branches in a radial format. It offers a powerful e-learning and organizational technique that visually displays main topics, subtopics, concepts and images and the relationships between them. Thus, Ruffini (2008) defined electronic mind maps as computer-generated mind maps that can represent complex information in an organized, easy-to-understand visual format .In addition, E- mind mapping is a powerful e-learning and organizational technique that can visually display main topics, subtopics, concepts, images and the interrelationships between them. In digital based mind mapping the output is a software file (PDF, image file, and html) while pen-based is a paper. In addition, digital-based mind maps 
can be linked with some other files i.e. Multimedia Files or Hyperlinks. Thus, it is clear how e-mind maps or digital mind maps are linked to the pen based mind maps. The digital mind map is designed by either computer programs or smart phones applications or Websites to be used in the digital or electronic world. Thus, Al-Badwoi (2015) investigated the impact of software based Mind Mapping (SMM) performed by tablets, mobiles, desktop and web school work on learning English.

Nowaday, with the development of Information Technology, humans tend to require accurate and reliable information. With the growing development of technology, the needs for a tool to solve the problems are increasing. Telegram application is capable of sending data into Messeger group of 5000 members and is able to handle all types of files that can be read by a mobile device or computer. Like a regular telephone, Telegram can read and write a list of contacts and send messages in the form of SMS and email .The speed of social networking sites technology is growing increasingly and dominates all aspects of people's lives. Thus, this technology plays a great role in education and learning. As a result of the Internet and mobile devices, mobile learning causes the learners use the technology such as Telegram and Instagram more enjoyable and effective anywhere and anytime. Telegram is a nonprofit cloud-based instant messaging service. It is a cloud-based messenger applications and easy to be synchronized so that individual can access messages from a variety of devices such as tablets and computers with the amount of up to 1.5 GB per person for photo files, video and file sharing such as doc, zip, mp3 and others (Fathi, 2018, Chaniago \& Junaidi, 2019).

Naderi \& Akrami (2018) clarified that social networks are appropriate channels to have the effective and efficient communication. Recently, easy access to internet provides good opportunities for people around the world to have connection with each other beyond considering the actual distance between them. This connection can be possible in different modes such as chat, call and video connection through various 
available types of social networks including telegram, WhatsApp, Imo and etc.

Telegram is a social network through which many online users chat and have social interactions. It is a messaging application with a focus on speed, security and usable across multiple platforms simultaneously. It also allows users to broadcast messages to large audiences publicly with its channel function. Ghobadi \& Taki (2018) clarified that Telegram as a social network tool is becoming one of the major tools for education and entertainment. It is one of the social networking applications that has many stickers with written English words and expressions. Users can even communicate without any text and only through images and stickers. Stickers are playing a significant role in communication through Telegram .It is also used as a tool to connect the classroom to the experts and educators around the world who are interested in the use of social media in educational environments. In their study, Zarei, Darani \& Ameri-Golestan (2017) clarified that telegram application is mostly used via cellphones providing the ability to make groups and invite other users to join. All the participants were asked to give their mobile phone number to the researchers. Then, they were trained to run the application on mobile phones and tablet PCs and join online groups. This was done to make participants familiar with the online group and the things they needed to learn and do in that particular environment.

Aghajani \&Adloo (2018) state that telegram has applications useful for teaching and learning. It is also a technological tool which can nurture the student-teacher relationship by creating positive learning experiences for both parties. New communicative applications such as Telegram should not be used just for the sake of wasting time and chatting. There has to be a goal that the teacher is trying to reach. In their study, Shirinbakhsh \& Saeidi (2018) clarified the importance of using Telegram application in developing reading skills. Through using 
telegram, students learnt well by doing homework assignments in Telegram. They learn well by reading and re-reading materials through Telegram. The multimedia available in Telegram makes the learning experience much better. Moreover, students learn well by working with their partners in Telegram because they can ask questions whenever they fail to understand. They clarified that using reading strategies can be better demonstrated via the visual aids in Telegram than those in a regular book. They feel ease while learning and working with their cellphone and learn reading strategies better during the small group work in Telegram. Telegram helps students share different opinions regarding a task to be completed.

It can be concluded that digital mind maps provide teachers with tools to help students develop higher achievement in their reading skills. It includes critical and creative thinking elements that help develop students in their ability to comprehend and understand the meaning of a text. The focus of the students in content is improved and they can classify the content into small understandable units. It facilitates classroom communication, as well as deepens the learners' understanding of the passage.As a result, researchers conducted studies to develop English language skills through using digital mind mapping and telegram application at the university level such as. Bahadori \& Gorjian (2016) investigated the effectiveness of discourse structurebased mind mapping software on EFL students' vocabulary learning. Ellozy \& Mostafa (2010) confirmed that using a hybrid concept/mind mapping online strategy (E-mapping) is effective in developing critical reading skills in first year Egyptian students enrolled at the American University in Cairo. Sabbah (2015) explored the effect of college students' self-generated computerized mind maps on their reading comprehension and attitudes toward generating computerized mind maps for reading comprehension. 
Moreover, Tungprapa (2015) investigated the effect of using the electronic mind map on teaching and learning in educational research methodology course of Master's degree students in the Faculty of Education, Thailand. Bahadori \& Gorjian (2016) reported that using modern methods such as Mind Mapping software has a significant effect on learning new lexical items of foreign language learners. Kusmaningrum (2016) revealed that using mind mapping is effective in improving students' reading comprehension and writing achievements . Masoud \& Ibrahim (2017) investigated the effectiveness of using an eMind Mapping Software based program in developing vocabulary acquisition and use among second year English majors at the Faculty of Education.

Moreover, the previous studies have shown that online environment can be an appropriate device to help learning different language skills, increase students' motivation, confidence and attitudes towards learning English (Tabrizi \& Onvani ,2018). Telegram can be used to improve the English language skills. In his study, Fathi (2018) analyzed the possibility of blending conventional instruction with online instruction via a social networking applications, Instagram and telegram in EFL classrooms to motivate students and improve their reading comprehension ability. Ghobadi \& Taki (2018) investigated the effect of using Telegram stickers on improving EFL learners' vocabulary learning. Zarei, Darani \& Ameri-Golestan (2017) examined the effects of Telegram on Iranian EFL learners' vocabulary knowledge and the attitude of them towards vocabulary learning.

In their study, Heidari, Khodabandeh\& Soleimani (2018) revealed that innovative instructional approaches and Telegram mobilelearning/teaching specifically could provide new opportunities for the teaching-learning process. Telegram m-learning/teaching in particular helped students to perform better on narrative writing tasks. Khodabandeh (2018) examined the effect of storytelling through the use 
of Telegram on oral language of English foreign language (EFL) students. Moreover, Naderi \& Akrami (2018) investigated the effect of instruction through telegram groups on the learners' reading comprehension. Salehpour (2018) revealed that using Telegram application did have a significant effect on improving EFL learners' listening comprehension ability. Shirinbakhsh \& Saeidi (2018) investigated the effectiveness of social media, more specifically Telegram, as a presentation technique for teaching reading strategies. Also, Tabrizi \& Onvani (2018) confirmed that learning vocabulary through the social network (Telegram) was more effective than the traditional approach.

As a result the researcher used Telegram application with digital mind maps due to two main reasons. Firstly, it is widely used by the students and could not pose any problem of accessibility. Secondly, Telegram can provide students with a wide range of options like sending and receiving multimedia messages along with texts. Therefore, the present study focused on integrating telegram application into digital mind mapping for developing EFL critical reading and writing skills among student teachers at the faculty of Education.

\section{Context of the Study}

EFL critical reading and writing skills are neglected among students at the university level. In light of the researcher's experience in teaching at the university level and the review of previous studies related to EFL CR skills such as the study conducted by Abdel Halim (2011) revealed that fourth-year TEFL majors at Faculty of Education faced several problems in CR skills and their level was low. Abdelrasoul (2014) confirmed that critical reading skills are also neglected. In her study, Mohammed (2014) clarified that students suffered from weaknesses in their CR performance in English language as they used to produce words and sentences that are directly stated in a reading text when answering questions about it. Moreover, they used to read texts without enough consideration to important CR skills such as identifying 
the main idea in the text, detecting the author's purpose and tone, drawing conclusions, making comparisons, identifying cause and effect relationships and making inferences.

In his study, Yu (2015) indicated that students complained that they spent a lot of time reading many texts but they still had many difficulties in reading, not only when they did English tests, but also when they read in normal life. Also, they revealed that they had a little interest in reading English material and had to prepare for all kinds of tests. Abd Kadir, Subki, Jamal \& Ismail (2014) clarified that teachers usually did not emphasize on CR skills when teaching reading. They focused more on word attack skills, comprehension skills, and fluency skills. Therefore, it is necessary for teachers to teach students CR skills because these skills could help them to survive when they leave schools. For teachers, in order to produce critical readers, they should expose the students to CR skills, reading strategies and metacognitive skills and strategies when they teach reading.

Nasrollahi, Krishnasam \& Noor (2015) revealed that students had problems in CR skills. Their CR development was decreased because there are some concerns regarding their poor thinking skills. This may be due to the neglect of $\mathrm{CR}$ and thinking in the school curriculum. Helping EFL students develop CR can be a challenging undertaking. Bedeer (2017) clarified that students encountered difficulties in CR skills. Thus, she investigated the effect of a brain based learning program on developing English language CR skills. Mahfouz (2019) confirmed that students faced several problems while reading critically. Their level in $\mathrm{CR}$ is low. In her study, she investigated the effectiveness of using SCAMPER strategy in developing English CR skills.

In the case of EFL CW skills, it could be noticed according to the review of related studies ( Abdul Fattah ,2015, Ahmed, 2016, Madkour, Kotb \& Ramadan ,2016, Ahmed 2018, Zahran, 2018, El Ganzoury, Ghanem \& Hafez, 2019), that students face difficulty in writing in

\section{9}


general and $\mathrm{CW}$ in specific. They are required to produce ideas arranged logically and use an active group of vocabulary items and structures including discourse markers. They concentrated on structure rather than the writing process and the current technique they used was not effective. Thus, there are many reasons for students' weakness in CW skills, the most important of whichis the technique of teaching. Moreover, teaching aids such as computers and the Internet are very important and may positively influence students' CW. It seems that there is a need to adopt new techniques for teaching CW that may help students become better writers. Thus, teachers probably should start from the vocabulary enrichment, grammar review, planning content by organizing ideas for writing and drafting. They also should involve students to give feedback to their colleagues' writing. Peer feedback can facilitate students to be evaluated without being judged, students also may learn from their friends' mistakes and errors in writing. Khalil (2019) indicated that students could not express their ideas while writing and their critical thinking is low. She clarified the close link between critical thinking and CW.

To document the problem, the researcher conducted a pilot study on thirty students $(\mathrm{N}=30)$ enrolled in third- year English section at Faculty of Education, Benha University, Egypt. The pilot study consisted of an EFL CR skills test and an EFL CW skills test. The results of the study revealed that students expressed little interest related to CR. They focused only on answering the direct reading questions where the answers were stated explicitly. They did not know the meaning of some vocabulary, therefore they left the answer blank. Thus, the students' correct answer centered all on the comprehension questions at the literal level. In general, they have difficulties in CR skills. According to CW skills test, the pilot study revealed that some students were afraid from writing because they lost interest. They had low self-esteem for writing. This low self-esteem towards writing hindered their ability to be flexible writers. They had problems in mechanics, spelling, punctuation, 
grammar, sentence structure, width of margins, and so on with little attention to the development or style. They also felt that writing considered a difficult skill. Thus, there is a need for developing EFL critical reading and writing skills among student teachers.

\section{Statement of the Problem}

Based on the observation of the researcher, the results of the pilot study and taking into consideration some recommendations of related studies, she noticed students' level in EFL critical reading and writing skills is low. In spite the importance of EFL critical reading and writing skills, the level of third- year students enrolled in English section at Benha Faculty of Education in EFL critical reading and writing skills is low. Therefore, the present study aims at examining the effectiveness of integrating telegram application into digital mind mapping in developing student teachers' EFL critical reading and writing skills.

\section{Questions of the Study}

1- What are the EFL critical reading skills required for student teachers at the Faculty of Education?

2- What are the EFL critical writing skills required for student teachers at the Faculty of Education?

3- What are the features of digital mind mapping and telegram application based program for developing EFL critical reading and writing skills among student teachers at the Faculty of Education?

4- How far is digital mind mapping and telegram application based program effective in developing EFL critical reading skills among student teachers at the Faculty of Education?

5- How far is digital mind mapping and telegram application based program effective in developing EFL critical writing skills among student teachers at the Faculty of Education? 


\section{Hypotheses of the Study}

Based on the related studies and research questions, the following hypotheses were formulated:

1- There is a statistically significant difference between the mean score of the study participants in EFL critical reading skills on the pre and post administrations of EFL critical reading skills test in favor of the post administration.

2- There is a statistically significant difference between the mean score of the study participants in EFL critical reading sub-skills on the pre and post administrations of EFL critical reading skills test in favor of the post administration.

3- There is a statistically significant difference between the mean score of the study participants in EFL critical writing skills on the pre and post administrations of EFL critical writing skills test in favor of the post administration.

4- There is a statistically significant difference between the mean score of the study participants in EFL critical writing sub-skills on the pre and post administrations of EFL critical writing skills test in favor of the post administration.

\section{Method of the Study}

\section{A) Participants}

The participants of the study consisted of thirty- five students $(\mathrm{N}=35)$. They were chosen from third - year students enrolled in English section at Benha Faculty of Education, Egypt. The participants represented one group taught through using digital mind mapping and telegram application based program.

\section{B) Design}

The present study is a partially mixed research methodology. It combines both quantitative and qualitative methods of collecting data to help in bridging the gap between quantitative and qualitative research. 
To conduct the quantitative analysis the pre- post experimental group design was used. The study participants were tested before and after conducting the program. In addition, a qualitative analysis of the students' performance is provided.

\section{C) Instruments}

In order to fulfill thepurposes of the study, the following instruments were designed.

\section{A) An EFL Critical Reading Skills Test (CRST)}

The EFL critical reading skills test (CRST) was prepared by the researcher to measure EFL critical reading skills among third- year students enrolled in English section at Faculty of Education, Benha University, Egypt ( see appendix A).It was used as a pre-posttest (applied before and after implementing the program). The test consisted of (34) questions suitable forstudents' level and background knowledge (see appendix $\boldsymbol{B}$ ). The students required to read the passages and answer the questions followed them. The time of the EFL critical reading skills test lasted one hour. The researcher calculated time taken by each student finishing the test and the average was found to be one hour. The test was graded by the researcher. The total mark of the test is (34) marks. The questions of the test were multiple choice questions, thus the researcher gave (1) mark for the right answer and (0) for the wrong one.

\section{B) An EFL critical Writing Skills Test (CWST)}

The EFL critical writing skills test was prepared by the researcher to measure EFL critical writing skills among third- year students enrolled in English section at Faculty of Education, Benha University, Egypt ( see appendix $\boldsymbol{C}$ ). It was used as a pre-posttest (applied before and after implementing the program). The test consisted of writing two essays (see appendix D). The students are required to write two essays. The time of the EFL critical writing test lasted two hours. The researcher calculated time taken by each student finishing the test and the average 
was found to be two hours .The test was graded by the researcher through using a rubric prepared by her. The rubric consists of seven parts; each part has three items ranging from "3" marks to "1" mark. The students were given "3" marks when their performance is high and "1" mark when their performance is low (see appendix $\boldsymbol{E}$ ).

\section{C ) A Semi-Structured Interview}

The semi- structured interview was constructed to examine the importance of digital mind mapping and telegram application based program among third -year students enrolled in English section at Benha Faculty of Education, Egypt, and its effectiveness in developing EFL critical reading and writing skills. The interview took the format of face to face semi-structured interview. The researcher interviewed students one time at the beginning of the study, a second time in the middle and a third time at the end of the study to gain greater insight on their EFL critical reading and writing skills throughout ten weeks. The researcher generally asked the students about their participation in the program. She used open ended questions to avoid responding with yes-no (See Appendix F). Seven students participated in the interview and their responses were video recorded. The interview lasted for one hour. At the beginning of the interview, the researcher greeted the students and asked them to give brief self-introduction as a way to set the goal for the interview. Then, she told them the purpose of the interview and their own roles. If students did not understand any question, she could simplify it or change it .At the end of the interview, the researcher thanked the students for their participation.

\section{Determining the Validity of the Research Instruments}

The EFL critical reading skills test, the EFL critical writing skills test and the interview were submitted to a jury member. They were asked to determine the validity of the instruments in terms of clear instructions, items and its suitability for the students' level. They indicated that the tests and the interview instructions were clear and suitable for students' 
levels and background knowledge. Therefore, the tests and the interview were considered valid measures of EFL critical reading skills and EFL critical writing skills (Face Validity).To ensure the content validity of the tests and interview, they were developed in the light of a systematic and accurate review of literature and previous studies. This accurate and systematic review determined the general form of the tests and the interview questions and methods of correction. Therefore, the content of the tests and the interview was representative of the skills that were intended to be measured. Thus, the tests and the interview were valid having content validity.

\section{Determining the Reliability of the Research Instruments}

The reliability of the instruments was measured by using the testretest method. The instruments were administered to a group of thirdyear students enrolled in English section at Benha Faculty of Education, Egypt. Then, they were administered to the same group again after two weeks. The Pearson correlation between the two administrations was (0.89) at the 0.01 level. Therefore, the instruments were reliable.

\section{Digital Mind Mapping and Telegram Application Based program}

For achieving the aim of the study, the researcher designed digital mind mapping and telegram application based program. After assessing third- year students' EFL critical reading and writing skills, the study participants were required to attend digital mind mapping and telegram application based program (See appendix I).

\section{Aim of the program}

The program aimed at developing EFL critical reading and writing skills among third -year students enrolled in English section at Benha Faculty of Education, Egypt.

\section{Objectives of the program}

By the end of the program, third- year students will be able to:

- Identify fact to opinion in the text, provide reason on the analysis 
about fact and opinion in the text.

- Identify and determine whether the statements are true or false.

- Get a sense of the author's mood, tone, technique.

- Identify the author's point of view and purpose .

- Draw inferences based on cause/effect relationship.

- Predict coming events.

- Identify the purpose of the passage.

- Create links between ideas in writing.

- Accept and refuse ideas in writing.

- Present evidences and points of view in writing.

- Organize and evaluate evidence

- Draw conclusion in writing.

- Apply vocabulary Choice and grammar.

- Apply organization and mechanics correctly.

\section{Content of the Program}

The topics chosen for the program were selected from books and studies enriched with topics that motivate students. The program contained variety of topics, situations and discussions designed for developing EFL critical reading and writing skills. They were suitable for the third -year students enrolled in English section at Benha Faculty of Education, Egypt . They included such as; Tomasek (2009); Ellozy \&Mostafa (2010); Simonova (2013); Mohammed (2014); Tungprapa (2015); Yu (2015); Bahadori \& Gorjian (2016); NematTabrizi \& Saber (2016) ; Chaichompoo (2017) ; El Ganzoury, Ghanem \& Hafez (2019) \& Khalil (2019).

\section{Framework of the Program}

The treatment began in October 2019 and continued through December 2019. The researcher met the students three hours per week for ten weeks and also communicated with them via what's app messages, Facebook and Telegram groups. Week (1) was used for pretesting and week (10) was used for post testing. Each session was 
devoted to the following: introduction, objectives, procedures, the role of the researcher and students and finally the performance. During the instructional procedures, different sessions had different learning goals and different methods were applied.

The program was taught to the study participants by the researcher herself. It lasted ten weeks with sixteen instructional sessions and each session lasted for 90 minutes. At the beginning of the program, the researcher introduced to the students what they are going to do. First, she told them about the objectives of the program and what they are supposed to gain as a result of their participation in the program (Goal Setting). After that she told them about the importance of critical reading and writing skills. Then, she began to introduce the concept of digital mind mapping and telegram application and its importance for language learning and EFL critical reading and writing skills.

Following the introduction to the program, the rest of the program were instructional sessions through which the critical reading and writing skills were introduced .At the beginning of each session, the researcher told students the objectives of the session, the researcher's role, the student's role, the instructional materials that will be used, the activities they will perform and ways of evaluating their progress .At the end of the each session, the researcher gave students some activities related to what they had learned in order to be sure that they mastered the skills in each session (formative evaluation). At the end of the program, the researcher assessed the students' achievement after implementing the program using EFL critical reading skills test and EFL critical writing skills test(summative evaluation).

\section{Procedures of the Program}

The program went through six stages as mentioned by Al-Jarf (2010), Zarei, Darani, \& Ameri-Golestan (2017) \& Naderi \& Akrami (2018): orientation, presentation and modeling, guided practice, independent practice, extension activities, and assessment. 


\section{Orientation Stage}

1- The researcher tried to make the students familiar with the program by using several samples of text structure-based mind mapping software for some texts and asking the students to fill them in.

2- She created Whatsapp group, telegram and Facebook group as ways of communication technology devices in order to communicate with her students during conducting the program.

3- The researcher gave students some links that helped them in making digital mind mapping such as: Edraw Mind Map and MindMasterwhich students downloaded.

- The former is Edraw Mind Map : it is a free mind map freeware with rich examples and templates that make it easy to create mind maps, brainstorming diagrams, etc. It can visualize thinking and quickly arrange and organize work.

- The latter is MindMaster: it is a cross-platform and multifunctional mind mapping software. It provides effective mind mapping solutions for brainstorming and note-taking and project management. The program also focuses on collaboration capabilities such as task assignment, comment and teamwork.

4- She instructed the students to install Telegram software on their mobile devices.

5- The researcher asked students to create digital mind mapping by using the previous applications in several styles. Then ,she examined and gave advice to students regarding the digital mind map they created.

6- She divided students into groups. They worked in groups to generate their mind maps using a paper and colored pens. Then, they began to create the maps electronically.

\section{Presentation and Modeling Stage}

- The researcher trained students to use MindMaster or Edraw Mind 
Map. Every week the software is used to create mind maps for the critical reading and writing skills. A mind map begins with placing a target concept, skill or category in the middle of the screen. This concept or skill is used as a basis for grouping, categorizing and sub-categorizing vocabulary items. Branches radiating from the central category are drawn for the sub-categories. Sub-categories, examples and words are elicited from the students, grouped into related sub-categories and placed radiating out from the central category. The researcher introduces new words and related concepts attached to those known by the students.

- In the case of Telegram application, the researcher posted reading text with questions and asked students to make e-mind map to answer the question. In addition, the posts contained some information which they could use to review what they had been taught. Whenever the participants had problems, they could pose their questions and the researcher answered them when she got a chance to answer them. She also posted a topic and asked students to create a digital mind map as an activity to generate ideas for writing.

- First the researcher wrote some important vocabularies and ideas and the students shared their ideas in the Telegram group with the supervision of the researcher.

- After that a short time was given to the students to read the text for themselves and share the main idea of the text with each other.

- The researcher sent the audio file of the text in the group and the students could listen to it. Finally, the following critical reading questions and related exercises were answered in group with students' cooperation and researcher supervision.

- The students were supposed to share their related questions, ideas and problems just in the group not in private. They could chat with each other about the passage out of that time span but without receiving any feedback from the researcher.

- At the next step, the researcher controlled what had been shared in 
the group including some questions, answered the questions which were related to the previous session and corrected the students if it was needed and then started teaching of the new passage.

\section{Guided Practice}

- Students practiced connecting new information they taught in class with information they already know using MindMaster or Edraw Mind Map out of class. With the help of the researcher, the students make lists of critical reading and writing skills.

\section{Independent Practice}

- The students continued to use MindMaster or Edraw Mind Map at home and continue to add anything related to critical reading and writing. They are handed out questions that require them to group, classify or connect critical reading skills studied in the sessions, on their own, in the sessions or at home. They also performed critical writing activities .

\section{Extension Activities}

- The students used MindMaster or Edraw Mind Map to group, classify or connect critical reading and writing skills encountered in a reading text or the tasks they wrote on the basis of decoding, morphological, and semantic relationships. They can create those digital mind maps individually, in pairs or small groups. They can exchange their mind-maps, keep them in a folder or e-portfolio, and post them on Facebook group, telegram group or what's app group.

\section{Assessment}

- The students were given blank mind-maps and are asked to group, classify, and connect a set of critical reading and writing skills and post them on Facebook group, telegram group or what's app group. 


\section{Findings of the Study}

\section{A) Quantitative Analysis of the Findings}

The findings of the present research are presented in the light of the hypotheses of the research using the Statistical Package for Social Sciences (SPSS). The findings are stated as follows:

\section{Testing Hypothesis (1)}

The first hypothesis states; there is a statistically significant difference between the mean score of the study participants in EFL overall critical reading skills on the pre-and post- administrations of the EFL critical reading skills test in favor of the post administration .Table (1) presents the students' mean scores, standard deviations, $t$-value and level of significance of the pre and post assessment of the study participants in EFL critical reading skills.

Table (1): "t" test between the mean scores of the study participants in the pre and post assessment of the Overall EFL critical Reading Skills

\begin{tabular}{c|c|c|c|c|c|c|c}
\hline \hline Skill & Test & N & Mean & S.D & T-Value & D.F & Sig. \\
\hline \hline $\begin{array}{c}\text { EFL critical } \\
\text { Reading Skills }\end{array}$ & Pre & 35 & 12.2000 & 2.29834 & & & \\
\hline \hline
\end{tabular}

Table (1) showed that the study participants outperformed in the post administration of the overall critical reading skills, where "t-value" is (26.407) which is significant at the (0.01) level .Thus, the first hypothesis was supported.

\section{Testing Hypothesis (2)}

The second hypothesis states; there is a statistically significant difference between the mean score of the study participants in EFL critical reading sub- skills on the pre-and post- administrations of the 
EFL critical reading skills test in favor of the post- administration. Table (2) presents the students' mean scores, standard deviations, $t$-value and level of significance of the pre and post assessment of the study participants in EFL critical reading sub-skills.

\section{The second hypothesis has the following sub-hypotheses}

- There is a statistically significant difference between the mean score of the study participants in differentiating fact to opinionon the pre-and post-administrations of the EFL critical reading skills test in favor of the post- administration.

- There is a statistically significant difference between the mean score of the study participants in identifying cause and effecton the pre-and post- administrations of the EFL critical reading skills test in favor of the post- administration.

- There is a statistically significant difference between the mean score of the study participants in identifying the author's point of view and purpose on the pre-and post- administrations of the EFL critical reading skills test in favor of the post- administration.

- There is a statistically significant difference between the mean score of the study participants in making prediction on the pre-and post- administrations of the EFL critical reading skills test in favor of the post- administration.

- There is a statistically significant difference between the mean score of the study participants in making inference on the pre-and post- administrations of the EFL critical reading skills test in favor of the post- administration.

- There is a statistically significant difference between the mean score of the study participants in vocabularymeaning on the preand post- administrations of the EFL critical reading skills test in favor of the post- administration. 
Table (2): "t" test between the mean scores of the study participants in the pre and post assessment of the EFL critical reading Sub-Skills

\begin{tabular}{|c|c|c|c|c|c|c|c|}
\hline Skills & Test & $\mathbf{N}$ & Mean & S.D & T-Value & D.F & Sig. \\
\hline \multirow{3}{*}{$\begin{array}{l}\text { differentiating fact } \\
\text { to opinion }\end{array}$} & Pre & & 1.8286 & 0.66358 & & & \\
\hline & Post & 35 & 3.8571 & 1.03307 & 8.307 & 34 & 0.01 \\
\hline & Pre & & 1.6000 & 0.60391 & \multirow[b]{2}{*}{12.720} & & \\
\hline $\begin{array}{l}\text { Identifying cause } \\
\text { and effect }\end{array}$ & Post & 35 & 3.8000 & 0.79705 & & 34 & 0.01 \\
\hline \multirow{2}{*}{$\begin{array}{l}\text { identifying the } \\
\text { author's point of } \\
\text { view and purpose }\end{array}$} & Pre & & 2.3714 & 1.00252 & & & \\
\hline & Post & 35 & 5.6571 & 0.76477 & 18.598 & 34 & 0.01 \\
\hline \multirow{2}{*}{ Making Prediction } & Pre & & 2.3714 & 0.84316 & \multirow{2}{*}{12.696} & & \\
\hline & Post & 35 & 4.6857 & 0.63113 & & 34 & 0.01 \\
\hline \multirow{2}{*}{ Making inference } & Pre & \multirow{2}{*}{35} & 1.8571 & 0.73336 & \multirow{2}{*}{11.427} & & \\
\hline & Post & & 4.0286 & 0.66358 & & 34 & 0.01 \\
\hline \multirow{2}{*}{$\begin{array}{l}\text { Vocabulary } \\
\text { Meaning }\end{array}$} & Pre & \multirow{2}{*}{35} & 2.1714 & 0.70651 & \multirow[t]{2}{*}{13.994} & 34 & 001 \\
\hline & Post & & 4.6286 & 0.77024 & & 34 & 0.01 \\
\hline
\end{tabular}

Thus, table (2) indicated that the study participants were much better in the post administration than the pre administration in EFL critical reading sub-skills where " $t$ " value is (8.307) for differentiating fact to opinion, (12.720) for identifying the cause and effect ,(18.598) for identifying the author's point of view and purpose , (12.696) for making prediction,(11.427)for making inference and (13.994) for vocabulary meaning which is significant at the (0.01) level. Therefore, the second hypothesis was confirmed.

\section{Testing Hypothesis (3)}

The third hypothesis states; there is a statistically significant difference between the mean score of the study participants in EFL 
overall critical writing skills on the pre-and post- administrations of the EFL critical writing skills test in favor of the post administration .Table (3) presents the students' mean scores, standard deviations, $t$-value and level of significance of the pre and post assessment of the study participants in EFL critical writing skills.

Table (1): " $t$ " test between the mean scores of the study participants in the pre and post assessment of the Overall EFL critical writing Skills

\begin{tabular}{c|c|c|c|c|c|c|c}
\hline \hline Skill & Test & N & Mean & S.D & T-Value & D.F & Sig. \\
\hline \hline $\begin{array}{c}\text { EFL critical } \\
\text { writing Skills }\end{array}$ & Pre & 35 & 26.0571 & 2.49638 \\
\hline \hline
\end{tabular}

Table (3) showed that the study participants outperformed in the post administration of the overall critical writing skills, where "t-value" is (37.828) which is significant at the (0.01) level .Thus, the third hypothesis was supported.

\section{Testing Hypothesis (4)}

The fourth hypothesis states; there is a statistically significant difference between the mean score of the study participants in EFL critical writing sub- skills on the pre-and post- administrations of the EFL critical writing skills test in favor of the post- administration. Table (4) presents the students' mean scores, standard deviations, $t$-value and level of significance of the pre and post assessment of the study participants in EFL critical writing sub-skills.

\section{The fourth hypothesis has the following sub-hypotheses}

- There is a statistically significant difference between the mean score of the study participants in creating links between ideason 
the pre-and post-administrations of the EFL critical writing skills test in favor of the post- administration.

- There is a statistically significant difference between the mean score of the study participants in accepting and refusing ideas on the pre-and post- administrations of the EFL critical writing skills test in favor of the post- administration.

- There is a statistically significant difference between the mean score of the study participants in providing evidences on the preand post- administrations of the EFL critical writing skills test in favor of the post- administration.

- There is a statistically significant difference between the mean score of the study participants in organizing and evaluating evidence on the pre-and post- administrations of the EFL critical writing skills test in favor of the post- administration.

- There is a statistically significant difference between the mean score of the study participants in drawing conclusion on the preand post- administrations of the EFL critical writing skills test in favor of the post- administration.

- There is a statistically significant difference between the mean score of the study participants in vocabulary Choice and grammar on the pre-and post- administrations of the EFL critical writing skills test in favor of the post- administration.

- There is a statistically significant difference between the mean score of the study participants in organization and mechanics on the pre-and post- administrations of the EFL critical writing skills test in favor of the post- administration. 
Table (4): "t" test between the mean scores of the study participants in the pre and post assessment of the EFL critical writing Sub-Skills

\begin{tabular}{ccc|c|c|c|c|c}
\hline \hline Skills & Test & N & Mean & S.D & T-Value & D.F & Sig. \\
\hline \hline $\begin{array}{c}\text { Creating links } \\
\text { between ideas }\end{array}$ & Pre & & 3.8857 & 0.79600 & & & \\
Post & 35 & 7.0286 & 0.92309 & & 34 & 0.01 \\
$\begin{array}{c}\text { Accepting and } \\
\text { refusing ideas }\end{array}$ & Pre & & 3.1429 & 0.87927 & & & \\
Presenting evidences & Pre & 35 & 4.8286 & 0.74698 & & 34 & 0.01 \\
and points of view & Post & 35 & 5.0286 & 0.78537 & & 34 & 0.01 \\
Organizing and & Pre & & 2.8286 & 0.98476 & & & \\
evaluating evidence & Post & 35 & 6.0571 & 1.16171 & & 34 & 0.01 \\
Draw conclusion & Pre & & 3.4000 & 0.55307 & & & \\
Pocabulary Choice & Pre & 35 & 5.4000 & 0.55307 & & & \\
and grammar & Post & 35 & 12.2571 & 1.46213 & & & 0.01 \\
$\begin{array}{c}\text { Organization and } \\
\text { mechanics }\end{array}$ & Pre & & 4.0857 & 0.70174 & & & \\
\hline \hline
\end{tabular}

Thus, table (2) indicated that the study participants were much better in the post administration than the pre administration in EFL critical writing sub-skills where " $t$ " value is (15.602) for creating links between ideas , (8.812) for accepting and refusing ideas,( 13.095) for presenting evidences and points of view , (13.110) for organizing and evaluating evidence,( 14.083)for draw conclusion, (25.713) for vocabulary Choice and grammar and (16.292) for organization and mechanics which is significant at the (0.01) level. Therefore, the fourth hypothesis was confirmed. 


\section{B) Qualitative Analysis of the Findings}

At the beginning of the program, the students were afraid of reading and writing in general and critical reading and writing particularly .They focused only on literal questions where the answers are explicit in the reading passage. They felt frustrated when they did not know meaning of any word. They could not guess the meaning of unknown words, predict or infer the answer. They also avoided reading because they feared from making grammatical mistakes. They had problems in critical reading. Students did not learn how to critically engage with texts, understand how the texts are part of an intellectual relation and express their opinion about the texts they read. They were accustomed to reading comprehension questions and word attack. They also had problems in presenting their ideas, their writing was full of grammar mistakes and the ideas were disorganized. They could not use suitable vocabulary and expressions while presenting their ideas.

After participating in digital mind mapping and telegram application based program, students gained more confidence and began to read in a better way. They became able to read critically, evaluate the reading text and clarify the author's purpose. Their participation in digital mind mapping strategies and activities helped them to get involved in reading, writing and master different critical reading and writing skills required to them. In the interview data, seven students had similar positive reaction towards using digital mind mapping and telegram application based program. They clarified that participating in the program helped everyone to move forward in a clear direction. Everyone works to achieve common, shared goals. They also worked together, collaborating and co-operating to make progress. In the case of critical writing, students gained more confidence and began to write in a better way. They used suitable vocabulary and expressions while presenting their ideas.

To understand how students perceived the importance of digital 
mind mapping and telegram application based program in developing EFL critical reading and writing skills, some interview questions were asked. Examples from the researcher's transcripts provided insight into the students' perception about the activities in digital mind mapping and telegram application. Students clarified that their critical reading and writing skills were improved because of the various activities that increased their desire to read and write. Therefore, it can be suggested that the steps of digital mind mapping and telegram application based program included activities and tasks that are effective in improving EFL critical reading and writing skills. The students' views in this regard are as follows:

Student (1): Using digital mind mapping and telegram application based program helped me to understand the information in the text clearly and in a motivating way .It was more interesting for me. It helped me a lot in learning new words and expressions.

Student (2):Through using Telegram mobile application, I learnt well by doing assignments in Telegram. I also learnt well by reading and re-reading materials through Telegram. I could express my opinion freely through writing.

Student (3): Digital mind mapping and telegram application based programwas an excellent tool for summarizing the text. Really, it helped me a lot in my reading and writing.

Student (4): Telegram application included a variety of multimedia that made the learning experience better. Moreover, I learnt well by working with my colleagues in Telegram because we could ask questions related to reading and writing.

Student (5): Digital mind mapping and telegram application based program assisted me in my study. Really ,it improved my study skills and provided me with various templates that made it easy to mind maps .

Student (6): I felt motivated and interested while learning and working 
with my cellphone and learnt critical reading and writing strategies better during the small group work in Telegram. Telegram helped me and my peers shared different opinions regarding a task to be completed.

Student (7): Digital mind mapping and telegram application based programincluded different activities that developed my critical writing .

\section{Discussion of the Results}

The primary purpose of the present study was to develop student teachers' EFL critical reading and writing skills through using digital mind mapping and telegram application based program. The program included variety of tasks and activities for helping students to enhance their EFL critical reading and writing skills. The results of the study revealed that the program proved to be statistically and educationally significant in developing student teachers' EFL critical reading and writing skills. It can be clarified that using digital mind mapping and telegram application based program in language teaching in general and EFL critical reading and writing skills in particular helped to increase student teachers' EFL critical reading and writing skills. In addition, digital mind mapping and telegram application based program highlighted the role of various activities in enhancing EFL critical reading and writing skills. The use of digital mind mapping and telegram application based program particularly in language classroom provided non-threating and motivating learning environment which considered one of the essentials of language learning. It offered various means such as animation, pictures when presenting the information. This made learning more interactive, interesting and fun.

Through participating in the program, students expressed their opinion as readers of the texts through class discussions following reading the texts. First of all, they had a class discussion on what kind of texts they would like to read. The students were also encouraged to 
express their opinions before and after reading a text. These results are consistent with IÇMEZ (2009). In addition, students' critical reading skills are improved. They became able to judge the reading material and did not accept all the information they found in the text. As a result, they had positive attitudes towards reading text while reading it and became neutral while reading. They also read different types of texts and thought from different perspectives. They began to think while reading and being aware of what is being read. They also evaluated the reading text with all its aspects. These results are consistent with Karadağ (2014).

Student teachers became able to analyze and evaluate their ideas while writing critically. They justify and give evidence for their opinions. They also became able to compare and contrast ideas. They provided evidence and supported their points of views. These results are consistent with Khalil( 2019) who confirmed the effectiveness of a program based on brain based learning and emotional intelligence in developing EFL critical writing skills.

It can be concluded that, digital mind mapping as a pedagogical tool is significant instructionalmeans that effectively promoted learners' vocabulary as a reading skill. The results are consisted with Bahadori \& Gorjian (2016) who highlighted the importance of multimedia in language acquisition, promotion of learning skills and strengthen of cognitive abilities. They also reported that mind mapping software provided teachers with tools to help students develop their reading comprehension skills. Mind mapping software included critical and creative thinking elements that helped students develop their ability to comprehend and understand the meaning of a text. The focus of the students in content improved and they classified the content into small understandable units. It facilitated classroom communication, as well as developed the learners' understanding of the passage.

Moreover, Ellozy \& Mostafa (2010) clarified that E-mapping is a powerful active learning tool which went beyond developing strong reading skills and enhancing class participation. It enhanced critical 
thinking and helped students acquire visualization skills by which they could communicate ideas using imagery. It is also an assessment tool that permits instructors to gain insight into their students' analytical and synthetic skills. Mohaidat (2018) investigated the impact of the electronic mind map (IMind Map) on the development of reading comprehension. The findings showed that applying the electronic mind maps in teaching reading texts was effective.

After implementing the program, the student's EFL critical reading and writing skillswere improved. Students became able to guess the meaning of the words they did not know through understanding the context. They also had the ability to infer the meaning of new words and used structural clues to find the meaning and word parts. Their skills in using context to determine the meaning of simple and difficult words were improved. In addition, comprehension skills were improved. Students became able to identify the main idea and author's purpose. They also knew how to answer the implied detailed questions correctly and transition questions. They became able to draw conclusions and identify cause and effect relationship clearly. The results are consistent with Chaichompoo (2017) who clarified the benefits of using e-mapping in analyzing reading texts and opinions on the overall ideas.

By reading, students were able to identify which information was relevant to main ideas, resulting in an improved ability to answer the questions more correctly, drawing up more orderly and more precise mapping, and summarizing the passages more accurately. Moreover, AlJarf (2010) showed how mind-mapping software could be used to develop EFL freshman students' vocabulary using.

Amir, Ismail \& Hussin (2011) clarified that writing can be a very painful experience to some people who may not have enough ideas for 
writing. However, when writing is carried out collaboratively, whereby a few people are assigned to write certain sections and later put the sections together into a masterpiece. Thus, the individuals in the group may find the exercise rewarding and exciting. Unlike face-to-face meetings among the group members to discuss the drafts of the writing, blog or weblog would allow the members to communicate with another faster and more frequent, share their drafts faster, improve their drafts faster and produce their final written products with great satisfaction. Moreover, Alidmat \& Ayassrah (2017) indicated that writing tasks like copying or writing down dictated notes did not require cognition of any sort. Higher level writing tasks demanding evaluation, inference, comparison or examination were similarly of no use to the beginning writer who still should learn how to compose ideas. Sinaga \& Feranie (2017) clarified that writing is a part of teachers' job to help them in memorizing, making reports, planning and regulating, encouraging critical thinking skills, self-reflection over conceptual mastery and communicating. Thus, in a process writing, learners had better organization skills including the use of punctuation, capitalization, paragraph and essay development methods and techniques, use discourse markers more effectively, use vocabulary more appropriately, construct sentences more correctly and improve skills related to mechanics of writing as Özdemir \& Aydin (2015) clarified in their study.

\section{Conclusions}

The results of the study revealed that the participants' EFL critical reading and writing skills developed after implementing digital mind mapping and telegram application based program. The effectiveness of digital mind mapping and telegram application based program may be due to the various activities, tasks and strategies the researcher presented 
to the students. Through the implementation of the program, major findings of the study were considered as the students' chances for learning by doing and experiences, their belief for better learning and development of learning skills with fun and enjoyment. Moreover, they emphasized on certain personal developments such as thinking, selfconfidence, communication skills and team spirit and their consideration of instructor as a guide for learning.

It can be said that digital mind mapping and telegram application based program is one of the best approaches to develop student teachers' EFL critical reading and writing skills. It plays an effective role in developing EFL critical reading and writing skills. It is an effective way of getting information in and out of the brain. It helps students to actively engage in their learning, through connecting their prior knowledge to new information. It improves interaction between students and enhances group work and team spirit. It also provides students with opportunities to be involved in concepts, information and events through discussion, asking questions and obtaining information. It is one of the active learning strategies. When considering the advantages and positive outcomes of the program, it is clear that the program proved developing student teachers' EFL critical reading and writing skills. Thus, digital mind mapping and telegram application based program is more successful than the traditional teaching.

\section{Recommendations of the Study}

In the light of previous results, the following recommendations could be presented:

- English language teacher should be trained on using digital mind mapping and telegram application while teaching English to their students in different educational stages. 
- English language teacher should emphasize the development of the students' EFL critical reading and writing skills in the early educational stages to develop them in the following stages.

- Curriculum designers should make use of digital mind mapping and telegram application when designing English language courses and overcoming any teaching or learning problems.

\section{Suggestions for Further Research}

Based on the findings of the present research, the following implications for further research are suggested:-

- The effectiveness of digital mind mapping and telegram application based program in English language learning among students teachers at University level.

- The impact of digital mind mapping and telegram application based program on other language skills such as listening and speaking.

- The effectiveness of digital mind mapping and telegram application based program in enhancing students' critical thinking skills and motivation towards English language.

- The effect of using other strategies on developing students' EFL critical reading and writing skills. 


\section{References}

Abd Kadir, N. , Subki, R. N. S., Jamal, F. H. A., \& Ismail, J. (2014). The importance of teaching critical reading skills in a Malaysian reading classroom. In 2014 WEI International Academic Conference Proceedings. (pp. 208-219). Austria, Vienna.

Abdel Halim, S.M. (2011). Improving EFL majors' critical reading skills and political awareness: A proposed translation program. International Journal of Educational Research 50, 336-348.

Abdel Latif, O.L.I. (2012).The Effect of Using a Blended Learning Literature Based Program on Enhancing Critical Reading and Writing Skills and on Developing Literature Appreciation of First Year English Majors Faculty of Education. Unpublished doctoral dissertation, Minia university.

Abdelrasoul, M.M.(2014).Using Reading Circles Strategy for Developing Preparatory Students' Critical Reading Skills and Social Skills. Unpublished master thesis, Ain Sham University, Egypt.

Abdul Fattah, S.F.E.(2015). The Effectiveness of Using WhatsApp Messenger as One of Mobile Learning Techniques to Develop Students' Writing Skills. Journal of Education and Practice , 6(32), 115-127.

Aghajani, M., \& Adloo, M. (2018).The Effect of Online Cooperative Learning on Students' Writing Skills and Attitudes through Telegram Application. International Journal of Instruction, 11(3), 433-448

Ahangari, S. \& Sepehran, H.(2014). The effect of intertextuality on Iranian EFL learners' critical writing. Iranian Journal of Language Teaching Research 2(1), 85-98.

Ahmed, K. (2018). Teaching critical thinking and writing in higher education: an action research project. TEAN Journal, 10 (1), 74-84. 
Ahmed, M.A.A.S. (2016). Web Quest and EFL Critical Reading and Writing. Cultural and Religious Studies, 4( 3), 175-184.

Al-Badwoi, A.S.(2015). Using E-Mind Mapping in Learning at IBR I College of Applied Sciences. Global Journal of Computer Science and Technology: H Information \& Technology, 15(4), 46- 53.

Albeckay, E.M.(2014). Developing Reading Skills through Critical Reading Programme amongst Undergraduate EFL Students in Libya. Procedia - Social and Behavioral Sciences 123 , 175 - 181.

Alfallaj, F.S.S. (2017). Reading Competence of the Saudi EFL Learner: Empowering the Teachers through Linguistics. Advances in Language and Literary Studies, 8(3), 12- 17.

Alidmat, A.O.H. \& Ayassrah, M.A.(2017). Development of Critical Thinking Skills through Writing Tasks: Challenges Facing Maritime English Students at Aqaba College, AlBalqa Applied University, Jordan. International Journal of Higher Education, 6( 3), 82-90.

Al-Jarf, R. (2010). A model for enhancing EFL freshman students' vocabulary with mind-mapping software. Journal of Teaching English for Specific and Academic Purposes, 3, 509 - 520.

Al-Jarf, R.(2011). Teaching spelling skills with a mind-mapping software. Asian EFL Journal Professional Teaching Articles 53, 416.

Aljaser, A.M. M.(2017). The Effectiveness of Electronic Mind Maps in Developing Academic Achievement and the Attitude towards Learning English among Primary School Students. International Education Studies, 10(12),80- 95.

Alwattar, N. Y., \&Al-Balhan, E.M.(2018). The Effectiveness of the Emind Mapping Strategy for Sixth-Grade Students' Achievement Level in Learning Arabic Vocabulary in Kuwait. Available on line at www.educationalrev.us.edu.pl/e53/a10.pdf.Retrieved on 4-4-2019. 
Amir, Z., Ismail, K. \& Hussin, S.(2011). Blogs in Language Learning: Maximizing Students' Collaborative Writing. Procedia Social and Behavioral Sciences 18, 537-543.

Anuar , N.\& Sidhu, G.K.(2017). Critical reading skills: A Survey of Postgraduate Students' Perspective of Critical Reading. Pertanika J. Soc. Sci. \& Hum, 25 (S), 163 - 172.

ATAÇ, B.A.(2015).From descriptive to critical writing: A study on the effectiveness of advanced reading and writing instruction. Procedia Social and Behavioral Sciences, 199 , 620 - 626.

Bahadori, A. \& Gorjian, B. (2016).The Role of Mind Mapping Soft Ware in Developing EFL Learner's Vocabulary at the PreIntermediate Level. Journal of Applied Linguistics and Language Learning, 2 (1), 8-16.

Balıkçı, G.,\& Daloğlu, A.(2016).Critical Reading Discourse of PreService English Teachers in Turkey. The Electronic Journal for English as a Second Language, 20 (1), 1-19.

Bedeer, F.A. M.(2017). The Effect of A Brain - Based Learning Program on Developing Primary Stage Students' English Language Critical Reading Skills. Unpublished doctoral dissertation . Ain Shams University, Egypt.

Bulgurcuoglu, A.N.(2016).Relationship between critical thinking levels and attitudes towards reading habits among pre-service physical education teachers. Educational Research and Reviews, 11(8), 708712 .

Ceylan, M. \& Baydik, B. (2018).Reading skills of students who are poor readers in different text genres. Cypriot Journal of Educational Science 13(2), 422-435.

Chaichompoo, C.(2017). Using e-Mapping to Improve Reading Comprehension and Summary Skills of EFL Students. NIDA Jounal Language and Communication, 22(30),129- 138. 
Chang, J.H., Chiu, P.S., \& Huang, Y.M.(2018). A Sharing Mind Maporiented Approach to Enhance Collaborative Mobile Learning With Digital Archiving Systems. International Review of Research in Open and Distributed Learning, 1 (1), 1-24.

Chaniago, M.B.\& Junaidi, A.(2019).Student Presence Using RFID and Telegram Messenger Application: A Study in SMK Unggulan TerpaduPgii Bandung, Indonesia. International Journal of Higher Education, 8(2), 94-102.

Damaianti ,V.S. , Damaianti, L. F.\& Mulyati, Y.(2017). Cultural Literacy Based Critical Reading Teaching Material with Active Reader Strategy for Junior High School. International Journal of Evaluation and Research in Education (IJERE),6(4),312-317 .

El Ganzoury, B.N.S., Ghanem, A. \& Hafez, H.(2019). Developing the Preparatory Stage Students Critical Writing Through a Virtual Reality Environmental Critical Writing Through A Virtual Reality Environmental Context. Educational Association for Teaching Languages, (8),45-58.

El-Attar , S.S.A.M.(2013).The Effect of a Suggested Program Based on Discourse Analysis and Metacognitive Awareness on Developing EFL Trainees' Critical Writing Skills and Foreign Language Cultural Awareness. Unpublished doctoral dissertation, Zagazig university.

Ellozy, A.R. \& Mostafa, H.M.H.(2010). Making learning visible: using e-maps to enhance critical reading skills. MERLOT Journal of Online Learning and Teaching, 6 (3), 634- 646.

Fathi, H.(2018). Blended language learning using social media networks (telegram vs. instagram) as pedagogical tool to enhance reading comprehension. Journal of Linguistics and Literature, 2(1), 30-35.

Ghobadi, S.\& Taki, S.(2018). Effects of Telegram Stickers on English Vocabulary Learning: Focus on Iranian EFL Learners. Research in English Language Pedagogy, 6(1), 139-158. 
Goctu, R.(2016).The Impact of reading for pleasure on Georgian University EFL students' reading comprehension .Journal of Education in Black Sea Region, 1(2), 73-81.

Haromi,F.A.( 2014).Teaching through appraisal: developing critical reading in Iranian EFL learners. Procedia Social and Behavioral Sciences, 98,127 - 136

Heidari, J., Khodabandeh, F.\& Soleimani, H.(2018). A comparative analysis of face to face instruction vs. telegram mobile instruction in terms of narrative writing. The JALT CALL Journal, 14(2), 143-156.

Ibrahim, Y.M.A.(2018). The effect of a suggested eclectic approach on developing EFL critical and writing skills for English Section Students at the Faculty of Education - Helwan University. Unpublished doctoral dissertation, Helwan university.

IÇMEZ, S. (2009). Motivation and critical reading in EFL classrooms: a case of ELT preparatory students. Journal of Theory and Practice in Education, 5(2), 123-147.

Jones, B.D.; Ruff, C.; Snyder, J. D.; Petrich, B.; \& Koonce, C. (2012).The Effects of Mind Mapping Activities on Students' Motivation. International Journal for the Scholarship of Teaching and Learning, 6 (1), 1-23 .

Kahu, E. R., \& Gerrard, H. (2018). The use of personal experience as a strategy for critical reading and writing. A Practice Report. Student Success, 9(3), 71-77.

Karabay, A. (2015). The guiding effects of a critical reading program on the use of external reading strategies when confronting an ironical text. Educational Research and Reviews, 10 (16), pp. 2296-2304.

Karaca, P.O. \& Oguz , F.G.(2017). A Conceptual Evaluation on Critical Reading. IOSR Journal Of Humanities And Social Science (IOSRJHSS) ,22 ( 12) ,38-41. 
Karadağ, R.(2014). Primary school teacher candidates' views towards critical reading skills and perceptions of their competence.ProcediaSocial and Behavioral Sciences 152,889 - 896.

Kedaj,P., Pavlíček, J.\& Hanzlík,P.(2014). Effective Mind Maps in Elearning. Acta Informatica Pragensia, 3(3), 239-250.

Khalil, A.H.S.A.(2019).A program Based On Brain Based Learning and Emotional Intelligence for developing EFL Secondary school Students Critical writing Skill. Benha faculty of Education Journal, 30(119), 51-75.

Khodabandeh, F.(2018). The impact of storytelling techniques through virtual instruction on English students' speaking ability.Teaching English with Technology, 18(1), 24-36.

Khonamri,F.\&Sana'ati,M.K. (2014). The Impacts of Dynamic Assessment and CALL on Critical Reading: An Interventionist Approach. Procedia - Social and Behavioral Sciences, 98 ,982989.

Kizilet, A. (2017). Investigation of critical thinking attitudes and reading habits of teacher candidates.Educational Research and Reviews, 12(6), 323-328.

Küçükoğlu, H.(2013).The interface between EFL teachers' self-efficacy concerning critical reading comprehension and some select variables.Procedia - Social and Behavioral Sciences, 70 , 1646 1650 .

Kusmaningrum, M.(2016). Using mind-mapping to improve reading comprehension and writing achievements of the 4th semester students of Stain Curup. Journal of English Literacy Education, 3( 2), 187-201.

Lestari, Z.W.(2015). The teaching of critical reading in an EFL classroom.International Journal of Social Sciences, 1(1), 519-530. 
Linh , N.D.(2016). The Development of an Instructional Design Model on Facebook Based Collaborative Learning to Enhance EFL Students' Writing Skills. The IAFOR Journal of Language Learning, 2(1), 48-66.

LIU, K.(2006). Annotation as an index to critical writing.URBAN EDUCATION, 41 (2), 192-207.

Madkour, A. ,Kotb, K.\& Ramadan, W.(2016).E-Learning strategy based on the reflective approach for enhancing Faculty of Education English Majors' critical writing skills. Educational Sciences Journal, 24(4), 35-52.

Mahfouz, M.A.(2019). The effectiveness of using SCAMPER strategy in developing English critical reading skills for first year secondary school students .Journal of Research in Curriculum, Instruction and Educational Technology ( JRCIET), 5 ( 4), 149-164.

Malkawi, N. A. M., \& Smadi, M.(2018). The Effectiveness of Using Brainstorming Strategy in the Development of Academic Achievement of Sixth Grade Students in English Grammar at Public Schools in Jordan. International Education Studies, 11(3), 92- 100.

Maltepe, S. (2016).An analysis of the critical reading levels of preservice Turkish and literature teachers. Eurasian Journal of Educational Research, 63, 169-184, http://dx.doi.org/ 10.14689/ejer.2016.63.10.

Masoud, H.M. \& Ibrahim, O.L.(2017). The Effectiveness of Using an eMind Mapping Software Based Program in Developing Faculty of Education 2nd Year English Majors' Vocabulary Acquisition and Use. Journal of Research in Curriculum, Instruction and Educational Technology (JRCIET), 3(4), 177-224.

Mohaidat , M.M.T.(2018) The Impact of Electronic Mind Maps on Students' Reading Comprehension. English Language Teaching, 11 (4), 32-42. 
Mohammed, M.M.K.(2014). The Effect of Using A Webquest Model To Develop Critical Reading Performance Among General Secondary Stage Students in Egypt. Arabian Universities libraries for education and psychology, Damascus university, 12(4), 1-42.

Naderi, S. \& Akrami, A. (2018). EFL Learners' Reading Comprehension Development through MALL: Telegram Groups in Focus. International Journal of Instruction, 11(2), 339-350.

Naderi, S., \& Akrami, A. (2018). EFL Learners' Reading Comprehension Development through MALL: Telegram Groups in Focus. International Journal of Instruction, 11(2), 339-350.

Nasrollahi , M.A., Krishnasam, P.K.N. \&Noor,N.M.( 2015). Process of Implementing Critical Reading Strategies in an Iranian EFL Classroom: An Action Research. International Education Studies, 8(1), 9-16.

Nemat Tabrizi, A. R.\& Saber, M.A.(2016). The Effect of Critical Reading Strategies on EFL Learners' Recall and Retention of Collocations. International Journal of Education \& Literacy Studies, 4 (4), 30-37.

Othman, H. K.(2018).The effectiveness of using mind mapping on the $3^{\text {rd }}$ graders' vocabulary learning and improving their visual thinking at UNRWA Schools. Unpublished master thesis, The Islamic University of Gaza.

Özdemir, E. \& Aydin, S.(2015). The effects of blogging on EFL writing achievement. Procedia - Social and Behavioral Sciences 199 , 372 - 380.

Öztürk, B.K.(2018). Evaluation of the Grammar Teaching Process by Using the Methods Used in Turkish Language Teaching as a Foreign Language: A Case Study. Universal Journal of Educational Research 6(2), 278-288.

Papushina, I., Maksimenkova, O., \& Kolomiets, A.(2017). Digital Educational Mind Maps: a computer supported collaborative learning practice on marketing master program. In M.E. Auer et al. (eds.) interactive collaborative learning, Advances in Intelligent Systems and Computing 544. 
Ruffini, M. (2008). Using E-Maps to Organize and Navigate Web- based Content. Interactive Educational Multimedia, 16, 87-98.

Sabbah , S.S.(2015). The effect of college students' self-generated computerized mind mapping on their reading achievement. International Journal of Education and Development using Information and Communication Technology (IJEDICT), 11 (3) , 4-36.

Salehpour, F.(2018). The effect of using telegram instant messaging application on listening comprehension skill among Iranian Intermediate EFL Students. International Journal of Educational Investigations, 5(3), 79-91.

Shirinbakhsh, S. \& Saeidi, F.(2018). The Effectiveness of Telegram for Improving Students' Reading Ability .Journal of Applied Linguistics and Language Research , 5(4),118-129 .

Simonova, I.(2013).Concept of E-learning reflected in mind maps of university students. Procedia - Social and Behavioral Sciences 116, $1394-1399$

Sinaga, P. \& Feranie, S. (2017). Enhancing Critical Thinking Skills and Writing Skills through the Variation in Non-Traditional Writing Task. International Journal of Instruction, 10(2), 69-84.

Sriwantaneeyakul, S.(2018). Critical Reading Skills and Translation Ability of Thai EFL Students: Pragmatic, Syntactic, and Semantic Aspects. English Language Teaching, 11( 4),1-14.

Sultan, Rofiuddin, A.; Nurhadi \& Priyatni, E. T.(2017).The Effect of the Critical Literacy Approach on Pre-service Language Teachers' Critical Reading Skills. Eurasian Journal of Educational Research 71,159-174

Tabrizi, H.H. \& Onvani, N.(2018). The Impact of Employing Telegram App on Iranian EFL Beginners' Vocabulary Teaching and Learning.Applied Research in English Language, 7(1), 1-18.

Tomasek, T.(2009). Critical Reading: Using Reading Prompts to Promote Active Engagement with Text. International Journal of Teaching and Learning in Higher Education, 21, (1), 127-132. 
Tungprapa, T.(2015). Effect of Using the Electronic Mind Map in the Educational Research Methodology Course for Master-Degree Students in the Faculty of Education.International Journal of Information and Education Technology, 5(11), 803-807.

Ulu,H., Avşar-Tuncay,A. \& Baş, Ö.(2017). The Relationship between Multimodal Literacy of Pre-Service Teachers and Their Perception of Self-Efficacy in Critical Reading.Journal of Education and Training Studies, 5(12), 85-91.

Yu, J.(2015). Analysis of Critical Reading Strategies and Its Effect on College English Reading. Theory and Practice in Language Studies, 5( 1), 134-138.

Zabihi,R .\& Pordel, M.(2011). An Investigation of Critical Reading in Reading Textbooks: A Qualitative Analysis. International Education Studies, 4(3), 80-87.

Zahran, F.A.(2018). The Impact of Project Based Learning on EFL Critical Reading and Writing Skills. Studies in Curriculum and teaching methods,(232), 38-72.

Zaki, E. M. F., Gheith, A.G., Nassar, R.F.\& Al Saify, Z.(2014). The Effect of using Electronic mind mapping on developing First Secondary Stage Student's EFL Critical Reading Skills. Journal of Knowledge and Reading, 157,1-21.

Zarei, R., Darani, L.H. \& Ameri - Golestan,A .(2017). Effect of Telegram Application on Iranian Advanced EFL Learners' Vocabulary Knowledge and Attitude. International Journal of Foreign Language Teaching \& Research, 5( 20), 95-109. 